\title{
studia
}

\section{Polskie badania nad filozofią brytyjskiego empiryzmu (lata 1760-1918) CZ. I.}

\section{Wprowadzenie}

Filozofia brytyjskiego empiryzmu, znana też w naszej literaturze filozoficznej jako Filozofia Oświecenia w Anglii, wiązana jest najczęściej z takimi postaciami, jak John Locke (1632-1704), David Hume (1711-1776), czy też Georg Berkeley (1685-1753). Obok wskazanych myślicieli trzeba jeszcze wymienić Francisa Bacona, Thomasa Hobbesa, Jonatana Benthama, Edmunda Burke’a, czy też Alexandra Pope’a. Osobno w tej „gamie” filozofów jest traktowany Isaac Newton. Wybiega on nie tylko poza ramy tworzonego wówczas empiryzmu, lecz podobnie jak Gottfried Wilhelm Leibniz, wykracza naukowo i tworzy podstawy nowego paradygmatu nauk filozoficzno-przyrodniczych. Dla tej opcji filozoficznej, jak pisze Władysław Tatarkiewicz w drugim tomie Historii filozofii, ważny był przede wszystkim „empiryzm, jako zasadnicze stanowisko filozoficzne Oświecenia. Zaczął się i rozwinął w Anglii. Postawy jego stworzył [zaś] jeszcze w końcu XVII w. Locke".

Polskie badania nad filozofią brytyjskiego empiryzmu w swych początkach miały różny przebieg. Przybierały zasadniczo zmienną postać. $\mathrm{O}$ ile bowiem możemy mówić o dość zaawansowanych badaniach polskich nad filozofią Leibniza, Spinozy, czy też Kanta, o tyle o naszych pracach nad brytyjskim 
empiryzmem z reguły wiemy niewiele. Dokonania w podjętych próbach recepcji mają charakter szczątkowy. Dotyczą zazwyczaj wybranego zagadnienia czy też omawiają dany problem w odniesieniu lub w relacji na przykład do filozofii Kanta. Dokonajmy w tej mierze koniecznej, bliższej prezentacji ${ }^{1}$.

\section{Polska recepcja filozofii Johna Locke’a do 1918 roku}

Jedną z pierwszych prac Locke’a przetłumaczonych na język polski były jego Myśli o wychowaniu, które ukazały się w Warszawie w 1781 roku. Był to przekład dokonany przez pijara ks. Edmunda Truskolaskiego na podstawie francuskiego wydania dzieła Locka. Ukazał się on jako cz. I i II Książki o edukacji dzieci. W okresie późniejszym doszło do dwóch kolejnych wznowień przekładu pracy Locke’a. Ukazały się one w Warszawie również w tłumaczeniu Edmunda Truskolaskiego w 1801 roku ks. I i II (udział w tym przedsięwzięciu mógł mieć również J. Znosko) oraz w Warszawie w 1812 roku.

Kolejny przekład, innego dzieła Locke'a An Essay concerning Human Understanding, wyszedł z pod pióra ks. A. Cyankiewicza, kanonika św. Anny i akademika krakowskiego w Krakowie 1784 roku. Były to wyjęte z dzieła Locke’a fragmenty pt. Logika, czyli myśli z Lokka „O rozumie ludzkim”, liczące ogółem 206 stron. Swój przekład Cyankiewicz dedykował Hugonowi Kołłątajowi, rektorowi Akademii Krakowskiej. Dodać należy, że w tym czasie znane już było na naszym gruncie filozoficznym dzieło kontynuatora Locke’a, a mianowicie Logika Condillaca. Ukazało się ono w tłumaczeniu J. Znoski w Wilnie 1802 roku, kolejne w tłumaczeniu ks. dra D. Bugajewicza w 1793 roku najprawdopodobniej w Poznaniu, a także w tłumaczeniu Ignacego Potockiego w 1794 roku w Warszawie.

\footnotetext{
${ }^{1}$ W pracach, które prowadzimy od kilku lat w Zakładzie Filozofii Nowożytnej Instytutu Filozofii Uniwersytetu Wrocławskiego, postanowiliśmy zbadać głębiej ten trudny, lecz niezmiernie ciekawy obszar, a mianowicie okres od 1750 roku i lata wcześniejsze do 1917 roku. W swoich badaniach kierowaliśmy się przeprowadzonymi już kwerendami bibliotecznymi, a także wskazówkami z Bibliografii filozofii polskiej, opracowywanej od lat z inicjatywy Komitetu Redakcyjnego Biblioteki Klasyków Filozofii na podstawie materiałów zebranych przez Adama Bara. Są to tomy: obejmujące lata 1750-1830, Warszawa 1955, ss. 265; lata 1831-1864, opracowały A. Kadler i I. Raczyńska przy współudziale B. Skargi i A. Sawickiej, Warszawa 1960, ss. 411; lata 1865-1895, opracował zespół pod kierownictwem A. Kadler, Warszawa 1971, ss. 705; lata 1896-1918, z. 1, do druku opracowali A. Przymusiała i M. Młoczkowska z udziałem J. Jaworowskiego, Warszawa 1994, ss. 479 oraz z. 2, do druku opracowali A. Przymusiała i M. Młoczkowska z udziałem J. Jaworowskiego i P. Dlouhy, Warszawa 2002, ss. 391.
} 
Poza przekładami wskazanych prac Locke’a w polskiej, dawnej literaturze filozoficznej jego dokonaniami zajmowano się sporadycznie. W pierwszej kolejności wskazać należy na artykuł (choć obszerny, to jednak bardzo ogólny w swym charakterze) Michała Gliszczyńskiego (literat) pt. Lokk - jego $\dot{z} y c i e$ - ogólny charakter jego filozofii. Praca ta ukazała się w „Rozmaitościach Naukowych i Literackich" w Warszawie na przełomie 1859 i 1860 roku w t. 5, s. 103-152. Ukazała się również inna praca Michała Gliszczyńskiego, a mianowicie Rozbiór teorii Lokka o woli, duszy i Bogu. Opublikowano ją w „Myślach" w tomie prac zbiorowych, a wydał ją H. Przybysławski w 1862 roku. Praca liczyła ogółem 49 stron.

Innym jeszcze autorem, który podjął myśl Locke’a i poddał ją analizie, był Karol Libelt (filozof, dział narodowy, społecznik). W 1840 roku opublikował on na łamach „Tygodnika Literackiego” pracę pt. O filozofii przedmiotowej z podtytułem odnoszącym szczególnie do filozofii Schellinga i Hegla. Wiele też uwagi Libelt poświęcił w swojej pracy dokonaniom Locke’a i Bacona. Praca ta ukazała się fragmentami w numerach $3,4,5$ i 6 w t. 3 wspomnianego czasopisma.

Fragmenty swojej pracy, poświęcone filozofii Locke’a, uczynił również Jan Kanty Hieronim Stefan Rzesiński (prawnik, profesor Uniwersytetu Jagiellońskiego). Zrobił to w niedokończonym przez siebie dziele pt. Charakterystyka najnowszej filozofii, która we fragmentach ukazała się „Kwartalniku Naukowym Krakowskim” w t. 3 w 1836 roku (fragmenty na s. 211-214 były poświęcone filozofii Locke’a).

W naszym dawnym piśmiennictwie opublikowano także przekład pracy Martina Louisa Aimé (literata, profesora literatury i historii) O ksztattowaniu duszy. Psychologia i filozofia dla kobiet. Był to fragment, który ukazał się dzięki staraniom Marii Brzeziny-Sadowskiej w Wilnie w 1861 roku. Liczył on sobie ogółem 115 stron, a na stronach 45-54 znajdowało się omówienie polemiki Locke'a $\mathrm{z}$ Condillakiem o pochodzeniu duszy. Recenzję z tego przekładu napisał K. Kraszewski w „Tygodniku Ilustrowanym Warszawskim” w 1862 roku w nr 137 na s. 189-190.

W naszej literaturze filozoficznej znamy też jedną pracę anonimową, a mianowicie O mechanicznym charakterze naszego wieku. Zawiera ona omówienie wpływu filozofii Locke'a i innych brytyjskich przedstawicieli empiryzmu. Ukazała się ona w „Tygodniku Petersburskim” w 1830 roku w nr 2 i 3 w dwóch krótkich fragmentach, będących najprawdopodobniej przekładem z języka angielskiego. 
W latach 1872-1881 ukazywała się w Krakowie w zeszytach praca Władysława Deisenberga Dzieje filozofii prawa i państwa przedstawione na tle dziejów cywilizacji. W t. 1 tej pracy na s. 495-619 znajduje się obszerny rozdział poświęcony filozofii Locke’a.

W „Przeglądzie Pedagogicznym Warszawskim” w roczniku 2 z 1883 roku możemy znaleźć na s. 97-101, 153-155, 193-196, 385-387 publikowany w częściach artykuł Jana Władysława Dawida pt. John Locke jako pedagog. W 1895 w Warszawie Jan Władysław Dawid przełożył dzieło Herberta Roberta Quicka Reformatorzy wychowania. Zasady wychowania nowoczesnego, gdzie na stronach 190--218 znajduje się fragment poświęcony Locke’owi.

Z kolei w „Bibliotece Warszawskiej” w 1882 roku w t. 4 na s. 161-181 ukazał się artykuł Wojciecha Dzieduszyckiego Moraliści XII wieku. Autor omówił tam częściowo i ogólnie poglądy Locke’a. Swoje poglądy Dzieduszycki poszerzył w innej pracy, a mianowicie w Roztrzasaniach filozoficznych o podstawach pewności ludzkiej, wydanej w Lwowie 1893 roku, gdzie w „Dodatku” omówił poglądy epistemologiczne Locke’a.

Natomiast August Antoni Eger w Bibliotece Ekonomisty zawartej w czasopiśmie „Ekonomista Warszawski” z 1878 roku podał własną wykładnię J. Locke'a Two treatises on government, dzieła wydanego w 1690 roku w Londynie. Polskie omówienie można znaleźć w nr 40 „Ekonomisty Warszawskiego", na s. 6-7.

Hipolit Grzybowski napisał w numerze 226, na s. 2 i w 227 na s. 1-2 krótką notę o Locke'u i innych myślicielach nowożytnych. Był to artykuł pt. Najznakomitsi myśliciele $w$ dziedzinie filozofii historii, opublikowany w „Gazecie Polskiej Warszawskiej", w 1867.

Kazimierz Kraszewski w Encyklopedii Wychowawczej, w t. 7 z 1904 roku zamieścił artykuł poświęcony Locke’owi na s. 76-81.

Maksymilian Kawczyński (filolog germanista, profesor UJ) w „Szkole Lwowskiej" w roczniku 6 z 1883 roku na s. 408-410 podał własną wykładnię teorii idei Locke’a. Był to artykuł w formie listy zatytułowany Listy $z$ wystawy wiedeńskiej pisane przez nauczyciela do kolegi.

Biskup Miachał Nowodworski, redaktor „Przeglądu Katolickiego” w „Encyklopedii Kościelnej” w t. 1-17, w wydaniu z 1873-1891 zamieścił artykuł poświęcony Lockeowi.

Teofil Ziemba napisał i wydał w Lembergu w 1869 roku liczącą 112 stron pracę pt. Locke und seine Werze nach den für die Philosophie interressantesten Momentem dargestellt und gewürdigt. 
Władysław Ochenkowski w „Jahrbücher für Nationalökonomie und Statistik" wydawanym w Jenie w t. 34, s. 431-476 z 1879 roku napisał i opublikował artykuł pt. John Locke als National-ökonom.

Felicja Boberska w swoich Pismach zawarła fragment dotyczący filozofii Locke’a. Był to artykuł zatytułowany Zasady pedagogiczne Lockego pod względem kształcenia charakteru, s. 396-412. Praca pochodzi z 1893 roku i została opublikowana we Lwowie.

Stanisław Leopold Brzozowski opublikował w 1902 roku Warszawie pracę Co jest filozofia i co o niej wiedzieć należy, a w części pierwszej „Do Kanta” poświęcił fragment na stronach 93 do 103 „Locke’owi. Filozofii oświecenia w Anglii. Religii naturalnej, moralności niezawisłej. Berkeley’owi i sceptycyzmowi Davida Hume'a.

W "Archiv für Geschichte Philosophie” w numerze 24 berlińskim z 1910/1911 w zeszycie 2 ukazała się recenzja Stanisława Dunina-Borkowskiego z pracy Ersta Crousa Die religionsphilosophischen Lehren Lockes und ihre Stellung zu dem Deismus seiner Zeit, Halle 1910.

\section{Polskie recepcje filozofii Dawida Hume’a do $1918 \mathrm{roku}^{2}$}

We Lwowie w 1905 roku dr Jan Leopold Łukasiewicz i prof. dr Kazimierz Twardowski przełożyli i wydali D. Hume’a Badania dotyczace rozumu ludzkiego, ss. 249. Kolejne wydania tego przekładu ukazywały się 1919, s. 201, 1928, s. 202, i wyd. 4 w Krakowie w 1947 roku w opracowaniu Anny Hochfeldowej, s. 178 i wznowienie w 1977 roku, s. 231.

Władysław Daisenberg w nieukończonej przez siebie pracy Dzieje filozofii prawa i państwa przedstawione na tle dziejów cywilizacji w jej tomie pierwszym „Dzieje filozofii nowożytnej”, wydanej w Krakowie w jedenastu zeszytach w latach 1872-1881 omawia między innymi stanowisko filozoficzne $\mathrm{Hu}-$ me'a na stronach 709-912.

Władysław Dębicki w „Tygodniku Ilustrowanym Warszawskim” w tomie 9 i 10 z 1894 roku przestawił pracę pt. Wielkie bankructwo umysłowe. Rzecz o nowoczesnym skrajnym sceptycyzmie, gdzie poświęcił jeden $\mathrm{z}$ fragmentów tej pracy Hume'owi.

${ }^{2}$ Zob. T. Sieczkowskiego Polskojęzyczna bibliografie D. Hume’a, „Nowa Krytyka”, Wydanie Jubileuszowe, nr 20-21, 2007. Zawiera spis prac Hume'a wydawanych po 1945 roku. 
Adolf Dygasiński w „Dodatku Miesięcznym Do Czasopisma Przegląd Tygodniowy" z 1880 roku opublikował streszczenie do pracy T. Huxley’a Hume i jego filozofia, s. 489-513, 649-695.

Wojciech Dzieduszycki wydał we Lwowie w 1983 roku Roztrzasania filozoficzne o podstawach pewności ludzkiej, a Hume’owi poświęcił s. 165-173.

Antoni Tanger w „Przeglądzie Powszechnym Krakowskim” w tomie 14, 16 i 17 z 1887 i 1888 roku opublikował pracę Cuda i ich znaczenie dziejach Objawienia, gdzie znalazł się fragment o krytyce pojęcia cudu u Hume’a.

Bolesław Limanowski w Genewskim czasopiśmie „Równość” w roczniku $1 \mathrm{z} \mathrm{1879/1880}$ w numerach 1, 2, 3, 4, opublikował pracę Fizjokraci, industrialiści i socjaliści w epoce przedrewolucyjnej XVIII stulecia, pisał o poglądach Quesnaya, Hume'a i Schmitha.

Witold Skarżyński (ekonomista, agronom-ziemianin) wydał w Posen 1877 roku pracę Adam Shmith als Moralphilosoph und Schöpfer der Nationalökonomie. Ein Beitrag zur Geschichte der Nationalökonomie. Praca ta ukazała się ponownie w Berlinie w 1878 roku i jest to (m.in. na stronach 31-92) zestawienie poglądów Shmitha i Huma.

J. K. Potocki przełożył na język polski i wydał w Warszawie 1890 roku pracę Wallace Alfreda Russela (biologa, geografa, podróżnika) O cudach i nowoczesnym spirytyzmie. Na stronach 9-52 znajdziemy „Odpowiedź na Argumenty Hume’a W. E. H. Lecky'go i innych skierowane przeciwko cudom, s. 60-73.

Michał Gliszczyński w „Wizerunku Roztrząsań Naukowych” w tomie 6 z 1836 roku na stronach 61-106 nakreślił własny portret historyka filozofii, jego predyspozycji moralnych i intelektualnych, na podstawie analizy osiągnięć Hume’a w artykule pt. Hume.

W „Przeglądzie Poznańskim” w tomie 6 z 1848 roku na stronie 212 ukazała się anonimowa recenzja z pracy J. H. Burtona Life and correspondence of $D a$ wid Hume, Edinurgh 1846.

W „Tygodniku Petersburskim” z 1830 roku, jako cz. 1, w numerach 2 i 3, ukazało się omówienie i przekład dzieła $O$ mechanicznym charakterze. Praca bliżej nie zlokalizowana, zawierająca jednak obszerne uwagi o wpływie brytyjskiego oświecenia, zwłaszcza Locke’a, Hume’a, Reda i innych, na współczesną naukę i kulturę.

W „Wizerunku Roztrząsań Naukowych” w części 6 z 1835 roku na stronach 5-65 znajdują się przełożone na podstawie tekstu zamieszczonego w „Dublin University Magazine” uwagi o Ruchu umysłowym tudzież jego płodach w An- 
glii od początku dziewiętnastego wieku. Zawierają one odniesienia do Hume’a, Bacona i Benthama.

Władysław Biegański w „Krytyce Lekarskiej Warszawskiej” w roczniku 10 z 1906 roku w numerach 2, 3, 4, 5, 6, 7, 8 opublikował serię własnych odczytów na temat Pojęcia przyczynowości w biologii. Uwagi w odczytach od 3 do 5 były poświęcone przeglądowi krytycznemu i omówieniu zagadnienia związku przyczynowego u Hume’a, J. St. Milla, R. Avenariusa i E. Macha.

Henryk Bolcewicz (ksiądz, pedagog, Litwin z pochodzenia) w 1913 roku wydał w Warszawie liczącą sobie 103 strony pracę Kant a Hume. Praca ta we fragmentach weszła też do księgi pamiątkowej ku czci Maurycego Straszewskiego z 1910 roku. Recenzje z tej pracy napisał zaś B. Bornstein w „Książce Warszawskiej" w roczniku 13 z 1913 roku w numerze 10, s. 494-495, a także H. Bad w „Ruchu Filozoficznym Lwowskim” w roczniku 3 z 1913 roku w numerze 8, s. 195a-197a.

W „Kwartalniku Filozoficznym Krakowskim” w tomie 9 z 1931 roku, s. 195-210, opublikowana została napisana przez Wacława Wolskiego (inżyniera) w 1917 roku praca O prawie przypadku jako źródle poznania.

Stanisław Dunin-Borkowski w „Archiv für Geschichte Philosophie” w wydaniu Berlińskim w tomie 24 z 1910/1911 w zeszycie 2, s. 261-262 napisał recenzję z pracy Alfonsa Bilharza Descartes, Hume und Kant. Eine kritische Studie zur Geschichte der Philosophie, Wisbaden 1910.

\section{Polskie recepcje filozofii Georgia Berkeley’a do 1918 roku}

Feliks Jezierski w Warszawie w 1890 roku przełożył, wstępem O życiu i filozofii Berleley'a, s. IX-XXIX, poprzedził i wydał dzieło George Berkeley’a Rzecz o zasadach poznania. Ukazały się na temat przekładu dwie recenzje Ignacego Matuszewskiego w „Przeglądzie Tygodniowym Warszawskim” z 1890 roku w numerze 24, s. 305-306 i w „Tygodniku Ilustrowanym Warszawskim” w tomie 1 z 1890 roku na stronie 399.

W „Tygodniku Ilustrowanym Warszawskim” w 1894 roku w tomach 9 i 10 ukazywała się praca Władysława Dębickiego Wielkie bankructwo umysłowe. Rzecz o nowoczesnym skrajnym sceptycyzmie naukowo-filozoficznym. Zawiera uwagi i odniesienia do Berkeley’a, Descartesa, Pascala, Bayle’a, Hirnhayma, Hume’a, Kanta i wielu innych myślicieli. Na temat pracy Dębickiego toczyła się w ówczesnej prasie naukowej duża dyskusja. Wspomnieć należy o recenzjach i polemikach: Antoniego Złotnickiego w „Przeglądzie Tygodniowym 
Warszawskim” z 1894 roku w nr 49, s. 535-536, Józef Tokarzewski (pseudonim J. T. Hodi) napisał krótką pracę pt. Co to jest solipsyzm w „Ateneum Warszawskim" z 1895 roku w t. 2, s. 473-477, Czesław Jankowski napisał recenzję pt. Dwie książki w „Kraju Petersburskim” z 1895 roku w numerze 9, s. 3-5, powstawały też pomniejsze noty autorstwa Ignacego Matuszewskiego, Tadeusza Jeske Chińskiego, czy też L. Krzywickiego.

Julian Ochorowicz zamieścił artykuł poświęcony Berkeley’owi w Wielkiej encyklopedii powszechnej ilustrowane" w serii pierwszej, w t. 5-10, z lat 18911893.

Kazimierz Noiszewski w „Przeglądzie Tygodniowym Warszawskim” w roczniku 33 z 1898 roku w numerze 21 na stronach 247-249 opublikował pracę pt. Krytyka zasad poznania Berkeleya.

Juliusz Kleiner we Lwowie w 1910 roku na 28 stronach zarysował Pojęcie idei u Berkeleya.

W „Ruchu Filozoficznym Lwowskim” w roczniku 4 z lat 1914-1918 w numerze 7, na stronach 200a-201a ukazał się autoreferat Adama Znamirowskiego Berkeley a Schopenhauer. Fragment ze studium o idealizmie, wygłoszony na posiedzeniu Towarzystwa Filozoficznego w Krakowie w dniu 10 czerwca 1914 roku.

\section{Abstract}

Polish Studies in the Philosophy of British Empiricism (1760-1918) part I.

Polish studies on the philosophy of British empiricism had various courses. Polish studies on Leibniz, Spinoza or Kant were quite advanced, but we know but little about the research on British empiricism. The achievements of the attempts of early reception are rather vestigial. The first part of the article presents early Polish studies into the philosophy of Locke, Hume and Berkeley. 